\title{
The Use of a Screw Sealer in Implant Abutment Fixation
}

\begin{abstract}
EMANUEL ADRIAN BRATU1', LAURA CRISTINA RUSU2*, OLIMPIU LADISLAU KARANCSI ${ }^{2 *}$, SORIN GHEORGHE MIHALI
${ }^{1}$ Victor Babes University of Medicine and Pharmacy, Faculty of Dentistry, Department of Implant Supported Restorations, 2 Eftimie Murgu Sq., 300041 Timisoara, Romania

2 Victor Babes University of Medicine and Pharmacy, Faculty of Dentistry, Department of Oral Patholog, 2 Eftimie Murgu Sq., 300041, Timisoara, Romania

${ }^{3}$ Vasie Goldis West University, Faculty of Dentistry, Department of Prosthodontics, 94-96 Revolutiei Blvd., 310025, Arad, Romania

In implantology, osteo-integration, stability and implant handling force is the major challenge for determining success of treatment. The present study aims to identify whether the use of an antimicrobial adhesive between the implant body and the abutment changes the torque force required for the unit. By using an antimicrobial sealant it is intended to reduce the torque used on the implants to increase their stability and to create the optimal conditions for an good osteointegration.
\end{abstract}

Keywords: screw sealer, implant, microleakage

For many years, implant- abutment connections were the subject of evolution. They evolved from external to internal and then to conical connections, with the idea of maintaining better soft tissue and bone conditions. Another goal was to have a very good adaptation to the implant body in order to preventmicromovementand microleakege [1]. Still today we have many studies wich show bacteria to be present even inside conical connection implants [2, 3 ] and the use of clorhexidine is not eficient in decontaminating [4-6]. Even with modern implant connections, micromovement is still present, but the most important problem is immediate loading [7]. It has been demonstrated that implants need a initial insertion torque of about minimum $25-30 \mathrm{Ncm}$ in order to be loaded immediately, but some components have to be tightend at the same amount of force. This can lead to implant movement in the bone. Also it has been proved that a one abutment one time procedure may reduce bacterial contamination of implants [4]. The present study is about a substance used in industry for screw loosening prevention. Loctite 243 is a dimethacrilate ester combined with maleic acid, used in automotive industry for preventing screw loosenings and comes in the form of a blue liquid [8]. This is a in vitro study with several types of implants that shows that the use of this fluid enhances the stability of the connection and can prevent bacterial leakage, allowing the components to be tightend at a torque inferior to $20 \mathrm{Ncm}$, but offering a removal torque and a stability to the components equal or exceeding a tightening of 30 $\mathrm{Ncm}$.

\section{Experimental part}

Materials and methods

For this study 2 implant systems with different connection types were used. MIS SEVEN with internal hex, standard platform diameter $3.75 \mathrm{~mm}$, length 11.5 , and MIS $\mathrm{C} 1$ standard platform, diameter $3.75 \mathrm{~mm}$, length $11.5 \mathrm{~mm}$ with conical connection. We used different connections in order to prove the eficciency of the material for all implant systems.

The aim of the study was to verify the effect of LOCTITE 243 used on a titanium interface between abutment screw/multi unit abutment and implant body.

Pairs of each implant type were inserted into plastic mandibles, wich were kept at 37 degrees Celsius,

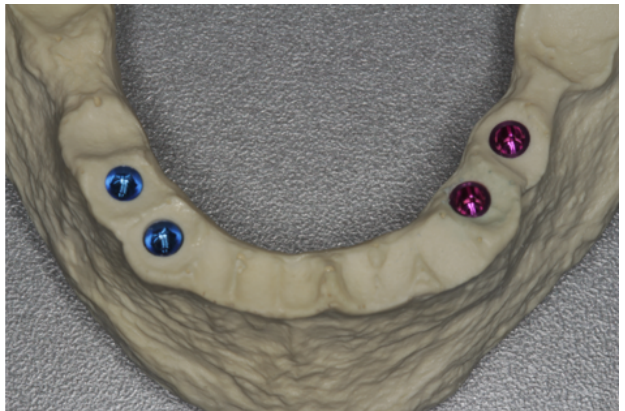

Fig. 1 The two types of implants transferred to the model

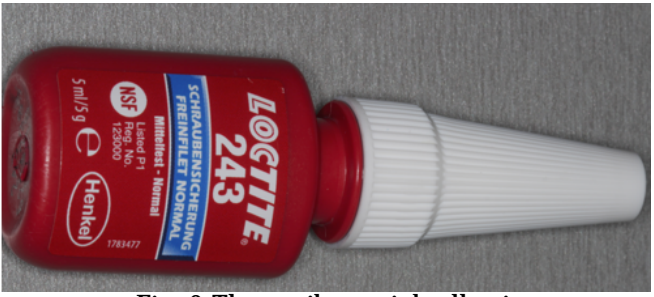

Fig. 2 The antibacterial adhesive

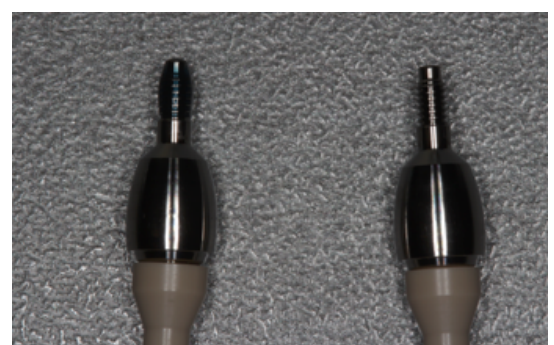

Fig. 3 The first pair of implants with and without adhesive

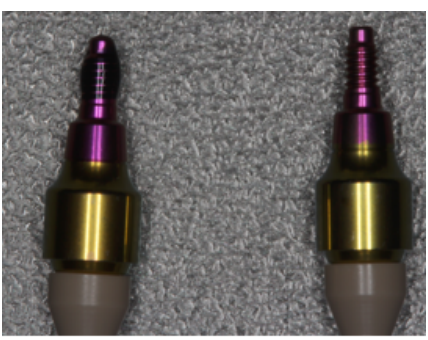

Fig.4 The second pair of implants with and without adhesive

*email: laura.rusu@umftro, Phone+40728700049; email: olilk@umftro, Phone: +40740203222 


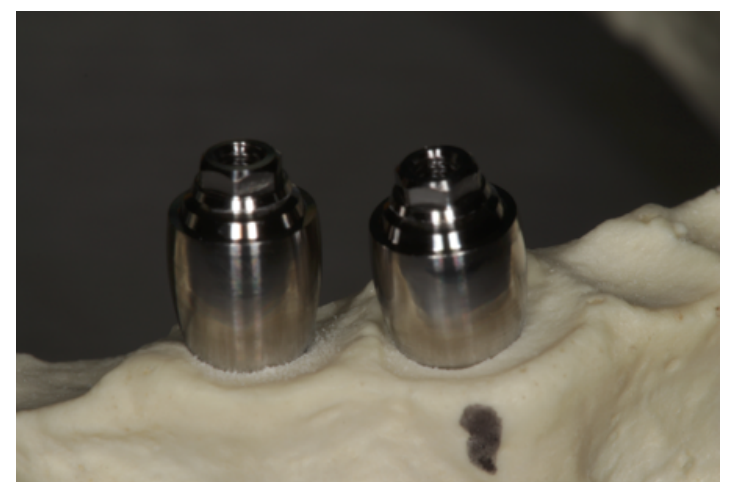

Fig 5. Implant assembly abutment for the first type of implants (right side of the mandible)

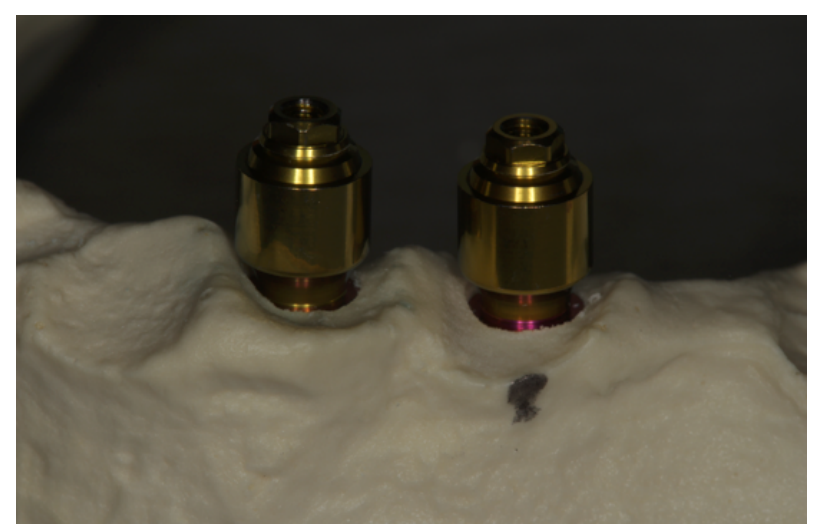

Fig.6 Implant assembly abutment for the second type of implants (left side of the mandible)

(incubator) for $24 \mathrm{~h}$ with a insertion torque between $50-60$ NCM.

This torque level was selected in order to simulate the possibility of immediate loading and osteointegration. It allows the fixation of the abutments with the torque recommended by the producer. One of each implant type recieved a multiunit abutment fixated with a torque wrench according to the manufacturer protocol $(20 \mathrm{Ncm})$ without any material inside, and another recieved a multiunit abutment screw immersed in LOCTITE 243 solution up to the last tread and immediately fixated with a torque wrench with a force of $15 \mathrm{Ncm}$. It is important to note, that there should be no excess of Loctite 243 coming out of the implant, and if so, it has to be immediately removed. Applying it only on the screw treads assures in most cases that no excess is observed. All implants were rinsed with saline solution and dryed out for $10 \mathrm{sec}$ using compressed air before abutment fixation in order to simulate clinical conditions. The same protocol was used with a standard straight abutment for cement retained restorations.

According to the manufacturer protocol of Loctite, the screws of the abutments were untouched for $24 \mathrm{~h}$. This is the setting time for Loctite on all materials tested before.

After this, a comparison was made for the reverse torque of the abutment screws fixated with and without Loctite 243.The measurements were taken with the use of the W\&H Implantmed device (W\&H Austria), using a angled handpiece and the original screwdrivers from each system. The Implantmed has a display wich can show the exact removal torque. We began with the same values of the insertion torque, increasing it by one NCM step by step, until the screw started to move.

\section{Results and discussions}

Removal torque of the abutment screw increased after $24 \mathrm{~h}$ with the use of Loctite 243 in all types of connections.
The removal torque of the components in internal hex implants (MIS Seven)fixated with Loctite 243 increased with $10 \mathrm{Ncm}$ at a level of $25 \mathrm{Ncm}$, compared to the fixation torque of $15 \mathrm{Ncm}$. In the $\mathrm{Cl}$ Conical connection implants the increase was higher, reaching $30 \mathrm{Ncm}$. The components fixated without Loctite had the same removal torque as the fixation torque. Allowing the material to set is important, so no movement of the screws is recommended for $24 \mathrm{~h}$, and also the material is not to be exposed to air longer than $5 \mathrm{~min}$, because it starts to set. These data are indicated in the sheets of the producer of Loctite. As implant component screws are made out of titanium and are very small we can equal them to the steel components of the industry with the smallest gaps. For the clinical use, it is important to assure that the interior of the implant shoud be clean and dry. This can be achived by the use of alcohol $96 \mathrm{grd}$, saline solution and airspray. Also it is better to fixate the multi unit abutment during the surgical time or after the use of a healing screw for at least 3 weeks. Fixation of the abutment at implant uncovery is the worst option because it is hard to keep out the blood from entering the interior of the implant, and then to dry it out as the flap is not elevated like in the surgical phase.

After 24 hours every implant wich recieved abutments fixated with LOCTITE 243 presented a higher value of the removal torque on the abutment screw. This shows that, if left untouched for $24 \mathrm{~h}$, Loctite is able to generate a higher removal torque. On the other side, the removal torque was not to big to generate forces that could eventually be of danger to the implant abutment interface.

Also, a very thin layer of Loctite was present at the implant platform, showing perfect closure of the small spaces on this interface. Inside the implant, Loctite filled all voids generated by the anatomy of the connection.

The authors have a 15 year clinical experience using this material in the same protocol.

Recently, several articles [9-13] report of the benefits of using threadlockers in prevention of screw loosening and bacterial infiltration. Some other articles report the influence of the implant abutment interface in aspects of bacterial microlikage[14-21] and the benefits of using sealing agents [22, 23].

\section{Conclusions}

Loctite 243 proved to be a efficient material in fixating and sealing out spaces between implant components. Because bacterial infiltration is documented even in conical connection implants[13], and a Poly anhidre ester showed antibacterial activity [24] we can assume that a good dosage of Loctite 243 (dimethacrilate ester combined with maleic acid) can eliminate bacterial colonization for all implant types. This is a important fact for the clinical use, and further in vivo studies have to be made in order to prove this fact $[22,23,25]$, and to prove that there is no inflammation of the soft tissues coming in contact with small amounts of Loctite.

\section{References}

1. MISHRA SK, CHOWDHARY R, KUMARI S Microleakage at the Different Implant Abutment Interface: A Systematic Review.J Clin Diagn Res. 2017 J un;11(6):ZE10-ZE15. doi: 10.7860/J CDR/2017/28951.10054. Epub 2017 Jun 1.

2. BAIXE S, TENENBAUM H, ETIENNE O Microbial contamination of the implant-abutment connections: Review of the literature]. Rev Stomatol Chir Maxillofac Chir Orale. 2016 Feb;117(1):20-5. doi: 10.1016/ j.revsto.2015.11.004. Epub 2015 Dec 30. 
3.BAGGI L, DI GIROLAMO M, MIRISOLA C, CALCATERRA R. Microbiological evaluation of bacterial and mycotic seal in implant systems with different implant-abutment interfaces and closing torque values. Implant Dent. 2013 Aug;22(4):344-50. doi: 10.1097/ ID.0b013e3182943062.

4.CALCATERRA R, DI GIROLAMO M, MIRISOLA C, BAGGI L Effects of Repeated Screw Tightening on Implant Abutment Interfaces in Terms of Bacterial and Yeast Leakage in Vitro: One-Time Abutment Versus the Multiscrewing Technique. Int J Periodontics Restorative Dent. 2016 Mar-Apr;36(2):275-80. doi: 10.11607/prd.2082.

5. SMITH NA, TURKYILMAZ Evaluation of the sealing capability of implants to titanium and zirconia abutments against Porphyromonas gingivalis, Prevotella intermedia, and Fusobacterium nucleatum under different screw torque values.J Prosthet Dent. 2014 Sep;112(3):561-7. doi: 10.1016/j.prosdent.2013.11.010. Epub 2014 Mar 20.

6. PODHORSKY A, BISCOPING S, REHMANN P, STRECKBEIN $P$, DOMANN E, WÖSTMANN B Transfer of Bacteria into the Internal Cavity of Dental Implants After Application of Disinfectant or Sealant Agents In Vitro. Int J Oral Maxillofac Implants. 2016 MayJ un;31(3):563-70. doi: 10.11607/jomi.4408.

7. SILVA-NETO JP, PRUDENTE MS, CARNEIRO TDE A, NOBILO MA, PENATTI MP, NEVES FD Micro-leakage at the implant-abutmentinterface with different tightening torques in vitro. J Appl Oral Sci. 2012 SepOct;20(5):581-7.

8.*** http://www.farnell.com/datasheets/24239.pdf

9. PIATTELLI A, SCARANO A, PAOLANTONIO M, ASSENZA B, LEGHISSA GC, DI BONAVENTURA G, CATAMO G, PICCOLOMINI R. Fluids and microbial penetration in the internal part of cement-retained versus screw-retained implant-abutment connections.J Periodontol. 2001 Sep;72(9):1146-50.

10. SELOTO CB, STRAZZI SAHYON HB, DOS SANTOS PH, DELBEN J A, ASSUNCÃO WG. Efficacy of Sealing Agents on Preload Maintenance of Screw-Retained Implant-Supported Prostheses. Int J Oral Maxillofac Implants. 2018 J anuary/February;33(1):123-126. doi: 10.11607/ jomi.5576.

11.OZDILER A, BAKIR-TOPCUOGLU N, KULEKCI G, ISIK-OZKOL G. Effects of Taper Angle and Sealant Agents on Bacterial Leakage Along the Implant-Abutment Interface: An In Vitro Study Under Loaded Conditions. Int J Oral Maxillofac Implants. 2018 September/ October;33(5):1071-1077. doi: 10.11607/jomi.6257. Epub 2018 J un 12. 12.DA SILVA-NETO JP, NÓBILO MA, PENATTI MP, SIMAMOTO PC $J R$, DAS NEVES FD. Influence of methodologic aspects on the results of implant-abutment interface microleakage tests: a critical review of in vitro studies. Int J Oral Maxillofac Implants. 2012 J ul-Aug;27(4):793800.

13. GUERRA E, PEREIRA C, FARIA R, JORGE AO, BOTTINO MA, DE MELO RM.

The Impact of Conical and Nonconical Abutments on Bacterial Infiltration at the Implant-Abutment Interface. Int J Periodontics Restorative Dent. 2016 Nov/Dec;36(6):825-831. doi: 10.11607/prd.2779.
14 TRIPODI D, VANTAGGIATO G, SCARANO A, PERROTTI V, PIATTELLI $A$, IEZZI G, D1/4ERCOLE $S$. An in vitro investigation concerning the bacterial leakage at implants with internal hexagon and Morse taper implant-abutment connections. Implant Dent. 2012 Aug;21(4):335-9. doi: 10.1097/ID.0b013e31825cd472.

15 ZIPPRICH H, MIATKE S, HMAIDOUCH R, LAUER HC.A New Experimental Design for Bacterial Microleakage Investigation at the Implant-Abutment Interface: An In Vitro Study.Int J Oral Maxillofac Implants. 2016Jan-Feb;31(1):37-44. doi: 10.11607/jomi.3713.

16 DIAS EC, BISOGNIN ED, HARARI ND, MACHADO S], DA SILVA CP, SOARES GD, VIDIGAL GM JR Evaluation of implant-abutment microgap and bacterial leakage in five external-hex implant systems: an in vitro study. Int J Oral Maxillofac Implants. 2012 Mar-Apr;27(2):346-51.

17 DO NASCIMENTO C, MIANI PK, PEDRAZZI V, GONCALVES RB, RIBEIRO RF, FARIA AC, MACEDO AP, DE ALBUQUERQUE RF JR. Leakage of saliva through the implant-abutment interface: in vitro evaluation of three different implant connections under unloaded and loaded conditions.Int J Oral Maxillofac Implants. 2012 MayJ un;27(3):551-60.

18GROSSM, ABRAMOVICH I, WEISSEI. Microleakage at the abutmentimplant interface of osseointegrated implants: a comparative study. Int J Oral Maxillofac Implants. 1999 Jan-Feb;14(1):94-100.

19 LARRUCEA C, CONRADO A, OLIVARESD, PADILLA C, BARRERA A, LOBOS O. Bacterial microleakage at the abutment-implant interface, in vitro study. Clin Implant Dent Relat Res. 2018 J un;20(3):360-367. doi: 10.1111/cid.12589. Epub 2018 Feb 15.

20 MENCIO F, PAPI P, DI CARLO S, POMPA G.Salivary bacterial leakage into implant-abutment connections: preliminary results of an in vitro study.Eur Rev Med Pharmacol Sci. 2016 J un;20(12):2476-83.

21 DO NASCIMENTO C, MIANI PK, WATANABE E, PEDRAZZI V, DE ALBUQERQUE RF JR.In vitro evaluation of bacterial leakage along the implant-abutment interface of an external-hex implant after saliva incubation.Int J Oral Maxillofac Implants. 2011 Jul-Aug;26(4):782-7.

22. OZDILER A, BAKIR-TOPCUOGLU N, KULEKCI G, ISIK-OZKOL G. Effects of Taper Angle and Sealant Agents on Bacterial Leakage Along the Implant-Abutment Interface: An In Vitro Study Under Loaded Conditions.Int J Oral Maxillofac Implants. 2018 September/ October;33(5):1071-1077. doi: 10.11607/jomi.6257. Epub 2018 J un 12. 23. RAMOS MB, PEGORARO LF, TAKAMORI E, COELHO PG, SILVA TL, BONFANTE EA. Evaluation of UCLA implant-abutment sealing.Int J Oral Maxillofac Implants. 2014 Jan-Feb;29(1):113-20. doi: 10.11607/ jomi.3217.cterial and Yeast $\mathrm{L}$

24.ASHLEY L. CARBONE-HOWELL, NICHOLAS D. STEBBINS, AND KATHRYN E. UHRICH Poly(anhydride-esters) Comprised Exclusively of Naturally Occurring Antimicrobials and EDTA: Antioxidant and Antibacterial Activities Biomacromolecules, 2014, 15 (5), pp 18891895

25. SELOTO CB, STRAZZI SAHYON HB, DOS SANTOS PH, DELBEN JA, ASSUNCAO WG Efficacy of Sealing Agents on Preload Maintenance of Screw-Retained Implant-Supported Prostheses. Int J Oral Maxillofac Implants. 2018 J anuary/February;33(1):123-126. doi: 10.11607/ jomi.5576. Epub 2017 Sep 22.

Manuscript received: 14.09 .2018 